\title{
Molecular Regulatory Mechanism of Exocytosis in the Salivary Glands
}

\author{
Akiko Suzuki ${ }^{1,2}$ and Junichi Iwata $1,2,3, *$ (1) \\ 1 Department of Diagnostic \& Biomedical Sciences, The University of Texas Health Science Center at Houston \\ School of Dentistry, Houston, TX 77054, USA; akikosuz925@gmail.com \\ 2 Center for Craniofacial Research, The University of Texas Health Science Center at Houston School of \\ Dentistry, Houston, TX 77054, USA \\ 3 Program of Biochemistry and Cell Biology, The University of Texas Graduate School of Biomedical Sciences \\ at Houston, Houston, TX 77030, USA \\ * Correspondence: Junichi.Iwata@uth.tmc.edu; Tel.: +1-713-486-2641
}

Received: 1 September 2018; Accepted: 11 October 2018; Published: 17 October 2018

check for updates

\begin{abstract}
Every day, salivary glands produce about 0.5 to $1.5 \mathrm{~L}$ of saliva, which contains salivary proteins that are essential for oral health. The contents of saliva, $0.3 \%$ proteins ( 1.5 to $4.5 \mathrm{~g}$ ) in fluid, help prevent oral infections, provide lubrication, aid digestion, and maintain oral health. Acinar cells in the lobular salivary glands secrete prepackaged secretory granules that contain salivary components such as amylase, mucins, and immunoglobulins. Despite the important physiological functions of salivary proteins, we know very little about the regulatory mechanisms of their secretion via exocytosis, which is a process essential for the secretion of functional proteins, not only in salivary glands, but also in other secretory organs, including lacrimal and mammary glands, the pancreas, and prostate. In this review, we discuss recent findings that elucidate exocytosis by exocrine glands, especially focusing on the salivary glands, in physiological and pathological conditions.
\end{abstract}

Keywords: exocytosis; salivary glands; Sjögren's syndrome; protein secretion; membrane trafficking

\section{Introduction}

The major (submandibular, sublingual, and parotid) and minor salivary glands produce $0.5-1.5 \mathrm{~L}$ of saliva daily, which is essential for oral health. Saliva comprises $99.5 \%$ of water, $0.3 \%$ of proteins, and $0.2 \%$ of both inorganic and organic substances [1]. The solid components differ from person to person, and from time to time in the same person. For example, salivary glands secrete 1.5 to $4.5 \mathrm{~g}$ proteins daily at a concentration of $0.47 \pm 0.19$ to $2.67 \pm 0.54 \mathrm{mg} / \mathrm{mL}$ [2]. The protein concentration in saliva is lower than that in tears, which is around $8 \mathrm{mg} / \mathrm{mL}$ under basal conditions [3,4]. Acinar cells are a major cell type within the salivary glands, responsible for the production and secretion of prepackaged secretory granules that contain key functional salivary components, such as amylase, mucins, and immunoglobulins [5]. These salivary components are functionally important for the digestion and taste of foods, lubrication, buffering, and prevention of dental caries, periodontitis, candidiasis and halitosis (bad breath).

This secretion process in exocrine glands, called exocytosis, involves secretory vesicle trafficking, docking, priming, and membrane fusion [6]. A failure during any of the steps in exocytosis in the salivary glands results in altered secretion of salivary proteins (Table 1). Interestingly, several studies show that secretion of salivary proteins is reduced, and the contents of saliva are also changed, in patients with dry mouth syndromes (e.g., Sjögren's syndrome) and in a mouse model for Sjögren's syndrome (e.g., non-obese diabetic (NOD) mice) [1,7-10]. This evidence suggests that exocytosis may 
be altered in various conditions, and the altered salivary contents may constitute a risk factor for major oral health issues [11,12].

There are two types of acinar cells-serous and mucous acinar-in the salivary glands. Serous acini are composed of typically 8-12 pyramid-shaped cells containing many secretory granules in the apical cytoplasm, a well-developed rough-endoplasmic reticulum (rough-ER), and pronounced round nuclei in the middle of the cytoplasm. They secrete serous saliva, which contains digestive $\alpha$-amylase (AMY1A), a protein that is crucial for food digestion $[13,14]$. By contrast, mucous acinar cells are larger than serous acinar cells and have flat nuclei towards the basal cell surface due to large numbers of mucin granules aggregated in the apical cytoplasm $[13,14]$. Mucous saliva contains mucins that are important for lubrication and oral health $[13,14]$.

The salivary glands secrete saliva rich in salivary proteins, the diverse functions of which maintain oral health by providing lubrication, initiating digestion, and offering first-line immunity. Therefore, disruption of salivary gland functions quickly results in widespread deterioration of oral health. Despite the important physiological functions of salivary proteins, we know very little about the regulatory mechanism(s) of exocytosis in the salivary glands. A detailed understanding of the mechanism(s) by which exocytosis is regulated will provide new knowledge of its key function(s), not only in the salivary glands but also in other secretory organs, including the lacrimal and mammary glands, the pancreas, and prostate, in physiological and pathological conditions. Ultimately, this approach will identify novel targets for therapeutics and contribute to new diagnostic tools for identifying exocytosis defects in at-risk populations such as those with high cholesterol levels or who have high-cholesterol diets.

Sjögren's syndrome is an autoimmune disorder characterized by lymphocytic infiltration of the exocrine glands, mainly the salivary and lacrimal glands, which results in reduced secretory functions and oral and ocular dryness $[15,16]$. The diagnosis is based on a combination of symptoms, physical examination, and blood tests (American-European Consensus Group, AECG, 2002; Sjögren's International Collaborative Clinical Alliance, SICCA, 2012). While the pathogenesis of Sjögren's syndrome remains elusive, various factors, including environmental, genetic and hormonal factors, seem to be involved, and either immune cells or exocrine gland cells are primarily damaged or disorganized to induce inflammation in the salivary and lacrimal glands [17-19].

Table 1. Phenotype in mice with deficiencies in genes related to the exocytosis process.

\begin{tabular}{|c|c|c|c|c|}
\hline \multirow{2}{*}{ Gene Name } & \multicolumn{3}{|c|}{ Mutant Mouse Phenotype } & \multirow{2}{*}{ Reference } \\
\hline & Salivary Acinar Cells & Lacrimal Acinar Cells & Pancreatic Acinar Cells & \\
\hline Vamp8 & $\begin{array}{l}\text { Accumulation of secretory } \\
\text { vesicles }\end{array}$ & $\begin{array}{l}\text { Accumulation of } \\
\text { secretory vesicles }\end{array}$ & $\begin{array}{l}\text { Accumulation of secretory } \\
\text { vesicles }\end{array}$ & [20] \\
\hline Syntaxin 2 & Not studied & Not studied & Increased exocytosis & [21] \\
\hline \multirow[t]{2}{*}{ Rab3d } & \multirow[t]{2}{*}{ Enlarged secretory vesicles } & $\begin{array}{l}\text { Enlarged secretory } \\
\text { vesicles }\end{array}$ & \multirow[t]{2}{*}{ Enlarged secretory vesicles } & \multirow[t]{2}{*}[22,23]{} \\
\hline & & $\begin{array}{l}\text { Decreased total protein } \\
\text { amount in tears }\end{array}$ & & \\
\hline Rab27a & Not studied & $\begin{array}{l}\text { Increased total protein } \\
\text { amount in tears }\end{array}$ & Not studied & {$[23,24]$} \\
\hline \multirow[t]{2}{*}{$R a b 27 b$} & \multirow[t]{2}{*}{ Not studied } & $\begin{array}{l}\text { Reduced number of } \\
\text { secretory vesicles }\end{array}$ & \multirow[t]{2}{*}{ Not studied } & \multirow[t]{2}{*}[23,24]{} \\
\hline & & $\begin{array}{l}\text { Increased total protein } \\
\text { amount in tears }\end{array}$ & & \\
\hline Noc2 & $\begin{array}{c}\text { Accumulation of enlarged } \\
\text { secretory vesicles }\end{array}$ & Not studied & $\begin{array}{l}\text { Accumulation of enlarged } \\
\text { secretory vesicles }\end{array}$ & {$[25,26]$} \\
\hline \multirow{2}{*}{$\operatorname{Sec} 23 b$} & Gland degeneration & \multirow{2}{*}{ Not studied } & Gland degeneration & \multirow{2}{*}{ [27-29] } \\
\hline & $\begin{array}{l}\text { Absent or reduced number } \\
\text { of secretory vesicles }\end{array}$ & & $\begin{array}{l}\text { Absent or reduced number } \\
\text { of secretory vesicles }\end{array}$ & \\
\hline
\end{tabular}




\section{The Exocytosis Process}

Exocytosis is a dynamic secretion process consisting of vesicle trafficking, tethering, docking, priming, and fusion [6,30]. After proteins are folded in the ER, they leave this organelle inside vesicles coated with the coat protein complex II (COPII) towards the Golgi apparatus. Through the trans-Golgi network, proteins are transported to various destinations by a variety of mechanisms. For example, the destination of the different proteins is determined by the molecule coats on a vesicle, by actin-dependent motors (Myosins), and by microtubule-dependent motors (Kinesins and Dyneins) [31,32]. During intracellular transportation, RAB GTPases and their effectors regulate the secretory vesicle movement throughout the cytoskeleton [33].

Soluble N-ethylmaleimide-sensitive factor attachment protein (SNAP) receptor (SNARE) proteins, such as vesicle-associated membrane proteins (VAMPs), are present in the secretory vesicle membrane (Figure 1). The secretory vesicles are transported from the trans-Golgi network via actin- and microtubule-based molecular motor proteins towards the plasma membrane. Once the secretory vesicles arrive to the plasma membrane, tethering factors (e.g., exocyst) promote trans-SNARE formation through interactions between RABs, MUNC18, and SNARE proteins [34]. Docking is the process during which the vesicle and plasma membrane line up in a fusion-ready state. Following docking, the plasma membranes fuse with the secretory vesicles to create a small pore that grows larger until exocytosis occurs. Membrane fusion and pore opening processes are similar to zippering [35-37].

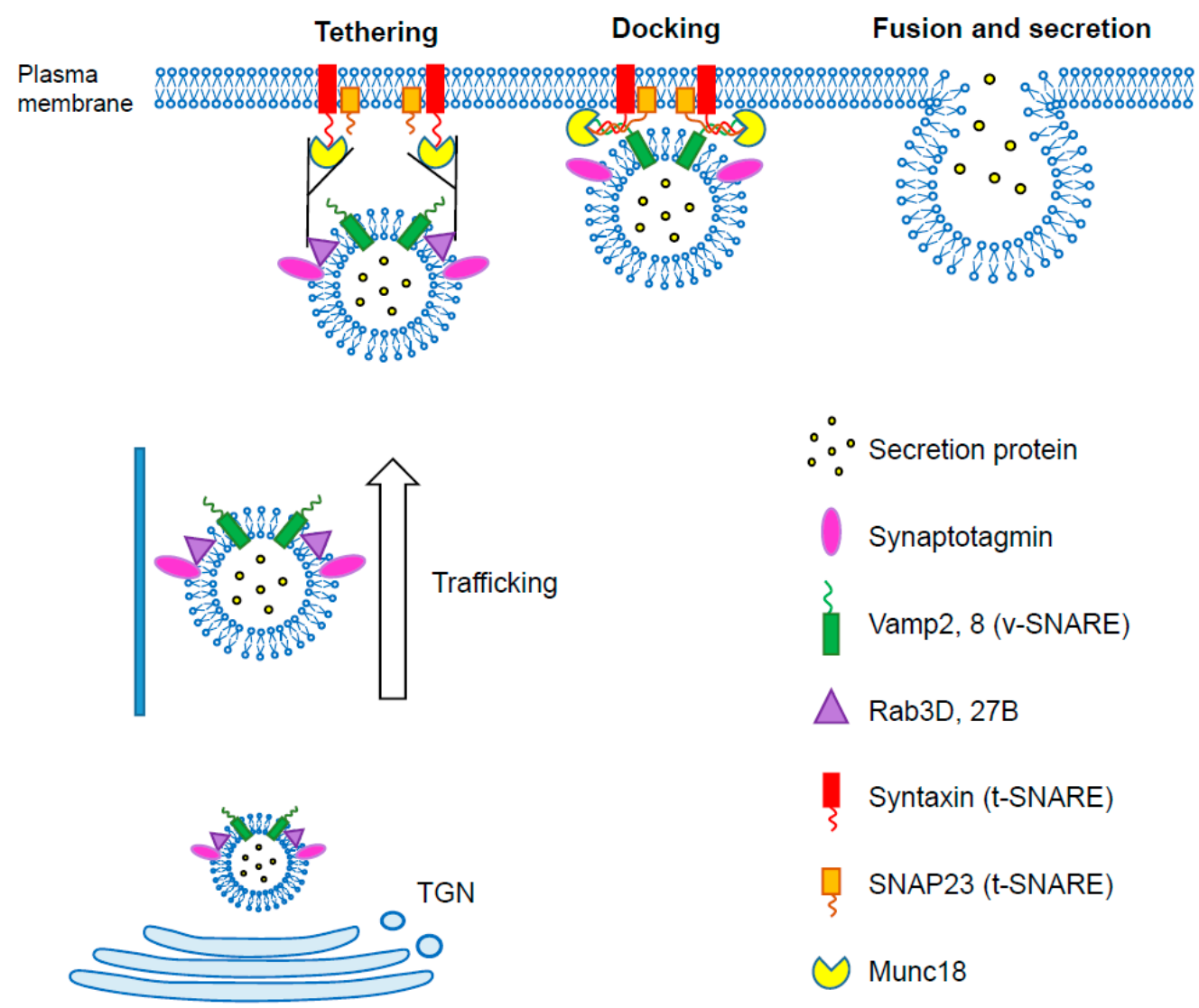

Figure 1. The exocytosis process. Exocytosis consists in secretory vesicle trafficking, docking, priming, and membrane fusion. These processes are regulated by soluble $\mathrm{N}$-ethylmaleimide-sensitive factor attachment protein receptor (SNARE) proteins and various accessory proteins. TGN, trans-Golgi network.

\section{SNARE Proteins}

SNARE proteins have been identified as regulatory molecules that are crucial for exocytosis [38]. SNARE proteins are small, abundant tail-anchored proteins that are often post-translationally inserted 
into the membranes via a C-terminal transmembrane domain [39]. They have a similar structure in a cytosolic domain that is known as the SNARE motif, which is characterized by coiled-coil sequences of 60-70 residues and heptad repeats [40]. SNARE proteins are subcategorized into $v$-SNAREs (proteins present in vesicles) and $t$-SNAREs (target proteins syntax) [40-42]. The $v$-SNAREs and $t$-SNAREs assemble in a twisted parallel four-helical bundle/four-strand coiled-coil structure (trans-SNARE complex) to form a complex that is incorporated into the membranes of transport vesicles during exocytosis [40]. The four-helix bundle is extremely stable and enables the vesicles to fuse with the plasma membrane, thus allowing the release of the vesicle contents [35,40]. SNAREs are also differently classified into R-SNAREs and Q-SNAREs. R-SNAREs act as v-SNAREs and contribute with an arginine (R) residue in the formation of the zero ionic layer which is the main site of interaction in the assembled core SNARE complex, whereas Q-SNAREs act as $t$-SNAREs and contribute with a glutamine $(\mathrm{Q})$ residue in the formation of the zero ionic layer in the assembled core SNARE complex $[38,43]$.

\section{3. $v$-SNARES}

\subsection{Vamp8/Endobrevin}

Vesicle-associated membrane protein 8 (VAMP8; aka Endobrevin) was first described as an R-SNARE of the early endosomal compartments [44], but recent studies indicate that it is an important component in exocytosis [45]. VAMP8 is enriched in zymogen granular membranes of pancreatic acinar cells and is crucial for regulated secretion [46]. Although mice deficient for Vamp8 $\left(V a m p 8^{-/-}\right)$are normal at birth, they display growth retardation and severe defects in the pancreas [46]. In the salivary glands as well as the lacrimal glands and other exocrine organs, Vamp $8^{-/-}$acinar cells show accumulation of secretory granules and increased levels of intracellular amylase and carbonic anhydrase VI, due to failure to interact with $t$-SNARE, Syntaxin-4, and SNAP-23 [20,46]. VAMP8 is also expressed in the apical plasma membrane in acinar cells and ductal epithelial cells in the major salivary glands and lacrimal glands [20]. In addition, $\operatorname{Vamp}^{-/-}$mice show reduced mucin secretion in airway goblet cells after stimulation with interleukin-13 (IL-13) [47]. VAMP8 expression in the lacrimal glands is altered, from the apical to the basal side, in individuals with dry eyes [48]; in Sjögren's syndrome, the expression of the gene and protein is decreased in the acinar cells of labial salivary glands. While VAMP8 is expressed in the apical cytoplasm in healthy individuals, it is expressed in the entire cytoplasmic in patients with Sjögren's syndrome [49]. Thus, VAMP8 plays a crucial role in exocytosis in various exocrine glands.

\subsection{Vamp2/Synaptobrevin2}

Vesicle-associated membrane protein 2 (VAMP2; aka Synaptobrevin) is a 19-kDa small protein that is crucial for vesicle fusion [41]. VAMP2 consists of a short $\mathrm{NH}_{2}$-terminal sequence (called SNARE motif) and a $\mathrm{COOH}$-terminal transmembrane region [50]. Mice deficient for Vamp2 exhibit a rounded body shape and a shoulder hump that is caused by excessive brown fat in the upper back [51]. While Vamp2 ${ }^{-1-}$ mice develop normally, they exhibit defects in $\mathrm{Ca}^{2+}$-triggered exocytosis of synaptic vesicles in neurons and chromaffin cells [51,52]. VAMP2 localizes at the secretory granular membrane in rat parotid gland acinar cells and regulates cAMP-dependent amylase secretion through interactions with Syntaxin-4 in the plasma membrane [53-55]; by contrast, VAMP2 interacts with Complexin-2 at the apical secretory granular membrane in rat pancreatic acinar cells [56,57]. In human submandibular glands, VAMP2 localizes at the apical plasma membrane of acinar cells [58].

\subsection{Synaptotagmins}

Synaptotagmins (SYT) are a family of vesicle membrane proteins distributed in both neuronal and non-neuronal tissues that comprise at least 15 isoforms in mammals [59-61]. SYT members have two $\mathrm{C} 2$ domains (C2A and $\mathrm{C} 2 \mathrm{~B}$ domains) that are important for $\mathrm{Ca}^{2+}$-dependent binding with the plasma 
membrane and SNARE proteins. Based on $\mathrm{Ca}^{2+}$ dependency in binding with phospholipids, SYT proteins are classified as $\mathrm{Ca}^{2+}$-dependent (SYT-1, -2, -3, -5, -6, -7, -9, and -10) and $\mathrm{Ca}^{2+}$-independent types. Syt1 and Syt3 are expressed in pancreatic acinar cells in mice and rats [57,62], whereas Syt1, $-3,-4,-7$, and -11 are expressed in the acinar cells of rat parotid glands $[63,64]$ and Syt1, $-2,-3,-4$, -6 , and -7 are expressed in the acinar cells of mouse parotid glands [63]. In the brain, Syt1 ${ }^{-1-}$ mice show a neurotransmitter secretion defect and synaptic transmission abnormality [65], and adrenal chromaffin cells exhibit reduced exocytosis in these mice [66]. Syt2 ${ }^{-1-}$ mice exhibit decreased and delayed neurotransmitter release at the synapse [67], and $S y t 7^{-/-}$mice show osteopenia because Cathepsin K secretion from osteoclasts and type I collagen secretion from osteoblasts are suppressed, resulting in decreased bone resorption and bone formation [68]. In addition, Syt7 $7^{-/}$mice show fibrosis in the skin and muscles and overactivation of the immune response, which is likely to cause autoimmune disorders [69]. Mice with a deficiency for either Syt3, Syt4, Syt5, Syt6, Syt10, or Syt11 show normal phenotypes and behavior. These studies suggest that there is functional redundancy among several SYTs, which can compensate for the functions of absent proteins in several knockout mouse models.

\section{4. $t$-SNARE}

\subsection{Syntaxins}

Membrane fusion, opposed by repulsive forces between phospholipid bilayers, causes electrostatic repulsion of equally charged membrane surfaces. To overcome these energy barriers, specialized fusion proteins are required $[37,70]$. Syntaxins (STXs) are categorized into Q-SNARE proteins, which are characterized by a SNARE motif (coiled-coil $\alpha$-helical structure), transmembrane domain (anchored C-terminal tail), and linker region [71]. The SNARE motif interacts with another molecule from the STX or SNAP family in order to form a $t$-SNARE complex. STX1A is expressed in presynaptic vesicles and forms a complex with SNAP25 and VAMP2 to induce synaptic exocytosis. Some STXs are expressed in exocrine acinar cells; for example, STX2 and STX3 localize at the apical plasma membrane, and STX4 is abundantly expressed in the plasma membrane in rat parotid glands. STX3 and STX4 form a complex with SNAP23 and VAMP8 in the apical membrane [55,72]. In human submandibular glands, STX2 is expressed in both the apical plasma membrane and cytoplasmic vesicles, and STX4 is expressed in the apical and basolateral plasma membranes [58]. In pancreatic acinar cells, STX4 is expressed in the basolateral plasma membrane while STX2 is present in the apical plasma membrane and zymogen granules, and STX-3, -7 and -8 are expressed in zymogen granules [73-75]. In terms of exocytosis, a few studies used St $x$ knockout mice. The pancreatic acinar cells from St $x 2^{-/-}$mice show increased exocytosis because of a failure in the inhibition of secretory vesicle fusion to the plasma membrane mediated by STX3 and STX4 [21]. The St $x 4^{-/-}$genotype is lethal before embryonic day 7.5 [76]. Mice with a heterozygous deletion of $S t x 4$ (St $x 4^{+/-}$mice) show reduced secretion of glucose-stimulated insulin from $\beta$-cells in the pancreatic islets [77]; on the other hand, Stx4 transgenic mice show increased insulin secretion [77]. In patients with primary Sjögren's syndrome, STX4 gene and protein expression is decreased in labial salivary glands, while STX3 gene and protein expression is increased, compared to healthy individuals. The intracellular expression patterns of STX3 and STX4 also dramatically change in patients with Sjögren's syndrome. While STX3 is normally localized in the apical region of acinar cells in labial salivary glands, STX3 is expressed in the entire cytoplasm and the basolateral plasma membrane in patients. STX4 localizes more abundantly at the basolateral plasma membrane than the apical plasma membrane in healthy individuals. In patients with Sjögren's syndrome, while STX4 localizes at the basal plasma membrane, similar to healthy individuals, its expression is decreased in the apical and lateral plasma membranes [49]. Interestingly, the number of STX4-VAMP8 and STX3-SNAP23 complexes is increased in acinar cells in the labial salivary glands of the patients. The STX4-VAMP8 complex is present in the basolateral membrane in patients while no STX4-VAMP8 complex has been detected anywhere in healthy individuals. Moreover, co-localization 
of STX4 and RAB3D, a small GTPase, in mature secretory vesicles in the subapical region is altered from the apical to the basolateral plasma membrane in Sjögren's syndrome patients. Corresponding to the disruption of expression and co-localization of SNARE complexes, secretory mucins (MUC5 and MUC7) are distributed not only in the cytoplasm but also in extracellular matrix in Sjögren's syndrome $[49,78]$. This suggests that inadequate expression of SNARE complexes leads to aberrant mucin exocytosis in the basal region, resulting in the accumulation of mucin in the extracellular matrix.

\subsection{SNAPS}

The SNAP25 family of proteins (SNAP25, SNAP23, SNAP29, and SNAP47) is included in the group of Q-SNARE proteins and anchor to the cytosolic face of the plasma membrane [79]. SNAP25 is expressed in the plasma membrane of neuronal and endocrine cells and forms a SNARE complex with STX1 and VAMP2. SNAP23 is a non-neuronal homolog of SNAP25 that is expressed in many cell types. In human submandibular glands, SNAP23 is specifically expressed in the apical membrane and the basolateral plasma membrane [58], but in rat parotid glands it can be detected in the apical plasma membrane and the intracellular membrane and interacts with STX3, STX4, VAMP2, and VAMP3 [72]. In rat pancreatic acinar cells, SNAP23 is expressed in the entire plasma membrane and zygomatic vesicles and forms a complex with SYN2 and VAMP2 in order to regulate exocytosis in the apical plasma membrane $[80,81]$. While SNAP23 is present in the plasma membrane of acinar cells in labial salivary glands of healthy individuals, SNAP23 expression is absent in the apical plasma membrane and remarkably decreased in the lateral plasma membrane in patients with Sjögren's syndrome, although its expression is not altered at the level of the basal plasma membrane [49]. Snap $23^{-1-}$ mice die at the pre-implantation embryonic stage [82], and hippocampal neurons from heterozygous Snap23 knockout mice show impaired recycling of $N$-methyl-D-aspartate (NMDA) receptors and decreased expression of NMDA receptors on the surface of the cells [83]. Snap $25^{-/-}$mice show decreased insulin secretion from $\beta$-cells and glucagon from $\alpha$-cells of islets as well as decreased glutamine release from synapses [84]. The exocytosis phenotype in the salivary glands and lacrimal glands of these mice has not been reported.

\section{3. $R A B$}

RAB proteins are members of the Ras superfamily of small GTPases (21-25 kDa). Until now, at least $70 \mathrm{RAB}$ proteins have been reported in mammals [85]. RAB GTPases are anchored at the cytosolic face of the intracellular membrane and play important roles in membrane trafficking such as vesicle formation, movement along the cytoskeleton, docking, priming, and membrane fusion processes during exocytosis. RAB proteins switch between active (GTP-bounding) and inactive (GDP-bounding) forms via GDP/GTP exchange factors (GEFs; activators) and GTPase-activating proteins (GAPs; inactivators). The GDP-bounding form is delivered to the appropriate membrane by $\mathrm{RAB}$ escort proteins and functions as a regulator of intracellular trafficking with RAB effector molecules, which are heterogeneous protein complexes involved in multiple functions, such as cargo selection, vesicle budding, movement throughout the cytoskeleton, tethering, and membrane fusion $[86,87]$. Previous studies indicate that several RAB proteins (RAB-1B, $-3 D,-4,-5 A,-11,-26,-27 A$, and $-33 A$ ), escort proteins, effectors (Slp4-a/granuphilin-a, Slac2-c/melanophilin, and Noc2/rabphilin 3A-like), and GEFs are expressed in rat parotid gland acinar cells [88-98]. Rab3d, Rab11a, Rab27a, and Rab27b are expressed in lacrimal gland acinar cells $[24,99,100]$. For example, RAB3A-3D is involved in regulated exocytosis, and RAB3D, but not RAB3A-C, is highly expressed in subapical secretory granules in acinar cells of the parotid glands, lacrimal glands, and the pancreas, and in synaptic vesicles in the brain $[95,96,101]$. While Rab3d null mice are not affected in terms of amylase secretion and number of secretory granules in acinar cells of the pancreas and parotid glands, the size of secretory vesicles is larger in Rab3d null mice compared to controls because of a failure in the maturation of secretory vesicles [22]. On the other hand, in the lacrimal glands of Rab3d null mice the total protein amount in tears is decreased [23]. Mice overexpressing Rab3d (Rab3d transgenic mice) show enhanced amylase 
secretion in pancreatic acinar cells under stimulation [102]. Mice with a deletion of Rab27a (Ashen mice) or Rab27b show slightly increased secretion of total protein in tears [23]. The number of secretory vesicles is significantly decreased in $R a b 27 b^{-/-}$and $R a b 27 a^{-1-}$; Rab27b $b^{-/-}$double knockout mice compared to control mice. Rab27a $a^{-/}$mice, as well as lacrimal gland acinar cells transfected with a dominant negative form of Rab27b, show a reduction in syncollin-GFP secretion in response to carbachol stimulation [24]. Interestingly, NOD mice, a mouse model for Sjögren's syndrome, show decreased Rab3d expression and altered distribution of RAB3D from the subapical vesicles to the basolateral region $[23,103]$. Both $\mathrm{Rab3}^{-/-}$and NOD mice show elevated expression and enzymatic activity of Cathepsin S, a secreted protease, in lacrimal gland acinar cells; by contrast, $R a b 27 a^{-/-}$and Rab27b $b^{-/}$mice show decreased Cathepsin S activity $[23,104]$. The total protein amount is inversely correlated with Cathepsin S activity in these mice [23]. Patients with Sjögren's syndrome show significant reduction in RAB3D expression, but not RAB8A, as well as the mislocalization of RAB3D from the apical to the basolateral region in salivary gland acinar cells $[49,105]$ and in lacrimal gland acinar cells [48]. The enzymatic activity of Cathepsin $\mathrm{S}$ is upregulated in tears from Sjögren's syndrome patients, as seen in $\mathrm{Rab3}^{-/-}$and NOD mice $[106,107]$. Taken together, RAB expression seems to be altered in the exocrine glands of patients with Sjögren's syndrome.

\section{Accessory Proteins}

\subsection{MUNC18}

MUNC18 (aka STXBP) is a Sec1/Munc18-like (SM) protein that includes three lobes folding into a clasp structure. MUNC18 binds to Syntaxin, is required for intermembrane trafficking in exocytosis, and is composed of six members [MUNC18-1 (aka STXBP1) to MUNC18-6 (aka STXBP6)]. MUNC18-1 is specifically expressed in the brain, and Munc18-1 null (Munc18-1-/-) mice die at birth as a result of cell autonomous neuronal degeneration [108]. Mice with a conditional deletion of Munc18-1 in the cerebellum (Munc18-1 flffl; Pcp2-Cre mice) show ataxia by 8 weeks old [109]. MUNC18-2 is expressed in acinar cells in the parotid glands and the pancreas and interacts with Syntaxin-2 in rats $[110,111]$. Mice deficient for Munc18-2 show decreased mucin secretion in airway epithelial cells and decreased histamine secretion in mast cells $[112,113]$. MUNC18-3 interacts with Syntaxin-4 in the apical membrane of parotid gland acinar cells and the basolateral membrane of pancreatic acinar cells for the regulation of amylase secretion in rats [114,115]. Munc18-3 heterozygous mutant mice show reduced insulin secretion in response to glucose stimulation in islets through granular delocalization to the plasma membrane [116].

\subsection{NOC2}

NOC2 (aka rabphilin 3A-like) is a putative RAB GTPase effector for RAB2A, RAB3, RAB8, and RAB27 that is widely expressed in endocrine and exocrine cells $[25,117,118]$. For example, Noc2 is expressed in acinar cells of the pancreas and salivary glands, granular convoluted duct cells in the submandibular glands, gastric chief cells, Brunner glands in the duodenum, Paneth cells in the jejunum, and mucous cells in the stomach. These cells are enlarged in $\mathrm{Noc}^{-/-}$mice due to the accumulation of enlarged secretory vesicles [26]. The increased size of secretory vesicles in Noc2 ${ }^{-/-}$mice is similar to that in $\mathrm{Rab3d}^{-/-}$mice [25]. Noc2 ${ }^{-/-}$mice release less insulin from the pancreatic islets and less amylase from pancreatic acinar cells compared to wild-type controls. Thus, NOC2 plays a crucial role in regulated exocytosis in both endocrine and exocrine cells.

\subsection{SEC}

Newly synthesized proteins are delivered to specific cellular organelles or the plasma membrane by cargo, which is sorted by COPII vesicles during transportation from the ER to the Golgi apparatus. The COPII coat contains a small GTPase SAR1 and two cytosolic protein complexes, Sec23/Sec24 and Sec13/Sec31. GDP-bound inactivated Sar1 interacts with Sec12, a membrane-bound GEF, and is 
exchanged with the GTP-bound active form. Activated Sar1 binds to a Sec23/Sec24 complex in the ER membrane, and finally the budding vesicle recruits a Sec13/Sec31 complex and then the COPII vesicle is released from the ER membrane [119]. SEC23 plays a role in COPII vesicle tethering to the Golgi $[27,120]$, and Sec13 suppression reduces the secretion and deposition of collagen fibrils and disturbs budding from the ER in Hela cells and human fibroblasts [121]. In addition, suppression of Sec13 in zebrafish results in craniofacial anomalies such as absence of Meckel's cartilage and disorganization of the neurocranium [121]. The phenotype is similar to that of crusher zebrafish, which has a mutation in Sec23a, and in patients with cranio-lenticulo-sutural dysplasia (CLSD) with mutations in SEC23A [122-126]. These studies suggest that SEC23A plays a role, not only in the capture of cargo, but also in the coupling of Sec23/24 and Sec13/31, which are both important for craniofacial development $[121,126]$. Patients with mutations in SAR1B have Chylomicron retention disease (CMRD), a hypocholesterolemic disorder characterized by lipid malabsorption. Mutations in $S A R 1 B$ result in impaired chylomicron trafficking from the ER to the Golgi and cause accumulation of prechylomicron-containing vesicles in the cytoplasm of enterocytes $[127,128]$. Mutations in SEC23B have been reported in congenital dyserythropoietic anemia type II (CDAII) $[129,130]$, and mice deficient for $\operatorname{Sec} 23 b$ (Sec23b $b^{\text {t/gt }}$ mice) display developmental defects in pancreatic acinar cells such as degeneration of acinar cells, absence of zymogene granules, accumulation of exocrine proteins in the ER, and dilated ER since the contents of the zymogen granules cannot exit from the ER via COPII vesicles [27]. Sec $23 b^{\text {gt/gt }}$ mice also show reduced body and pancreas size compared to controls at birth while there is no defect in hematopoiesis/number of red blood cells and skeletal development, which can be seen in CDAII and CLSD, respectively. In addition to pancreatic acinar cells, other exocrine glands (e.g., submandibular, sublingual, and nasal glands, gastric mucus epithelium, and goblet cells) are similarly affected in Sec23bgt/gt mice, including degeneration of acinar cells, dilated ER, and reduced or no secretory vesicles in these glands [27]. Mice with a pancreatic acinar cell-specific deletion of Sec23b (Sec23b flfll; Ela-CreErT) show phenotypes similar to those of Sec $23 b^{g t / g t}$ mice. The amylase amount in total lysate from pancreatic cells is slightly decreased in these Sec $23 \mathrm{~b}$ conditional knockout mice but is not affected in the plasma $[28,29]$. These results indicate that the inhibition of the early steps of trafficking results in the reduction in number of secretory vesicles.

\section{Other Potential Regulators}

\subsection{Lipid Metabolism}

It has long been appreciated that individuals with metabolic syndromes and unhealthy diets, including those with a high fat content, are at risk of a variety of oral diseases [131,132]. It has been suggested that salivary protein content is altered in patients with diabetes and obesity, who present a higher frequency of oral health issues [12,133-140]. A recent study indicates that altered salivary composition induced by high fat-diet obesity is restored with normal diets in Wistar rats [141]. Moreover, animal studies suggest that obesity induced by high-fat diets or atherogenic cholesterol-rich diets triggers periodontal disease as well as alveolar bone loss [142-144]. A low-fat, high-fiber diet, however, improves periodontal diseases [145].

\subsection{Neuronal Regulation}

The secretion of protein and water in the salivary glands is regulated by parasympathetic and sympathetic nerves. Denervation by parasympathectomy and sympathectomy results in reduction of saliva secretion, and subsequently atrophy, in animal models and humans [146-150]. However, it remains unknown whether denervation or neuronal dysfunction causes the Sjögren's syndrome-like phenotype. Since synaptic vesicle exocytosis is crucial for neural function, the link of Sjögren's syndrome and neuronal dysfunctions should be investigated in the future. 


\section{Conclusions}

Salivary proteins (amylase, mucin, and immunoglobulin) are functionally important for aiding digestion, providing lubrication, preventing oral infections, and maintaining overall oral health. Salivary proteins are secreted via exocytosis by acinar cells in the salivary glands. Despite its importance, the regulatory mechanism of salivary exocytosis has been elusive because of: (1) the lack of tools for tracking exocytosis, and (2) the lack of animal models with exocytosis defects in the salivary glands. The current limitation of mouse models is that almost all models for Sjögren's syndrome (or related dry mouth syndromes) have mutations and/or defects in the immune cells themselves [19]. Defects in each step of vesicle trafficking and membrane fusion processes may result in a failure of salivary protein secretion to the oral cavity as well as in the accumulation of secretory granules in acinar cells that may lead to the death of acinar cells. This might, in fact, be a trigger of inflammatory responses in pathogenesis and progression of Sjögren's syndrome. Further studies will contribute to the development of new tools to track exocytosis and to the development of new mouse models to understand the mechanism(s) of exocytosis in healthy individuals and in patients with Sjögren's syndrome.

Author Contributions: A.S. and J.I. wrote the paper. All authors reviewed and approved the final version of the manuscript.

Funding: This research was supported by the National Institutes of Health and the National Institute of Dental and Craniofacial Research (R03DE024759, R03DE026208, R01DE026767, and R03DE026509 to J.I.).

Acknowledgments: We thank Ryohei Minamide and Ankita Garg for assistance with the literature search and graphic drawing.

Conflicts of Interest: All authors state that they have no conflicts of interest.

\section{References}

1. Liu, J.; Duan, Y. Saliva: A potential media for disease diagnostics and monitoring. Oral Oncol. 2012, 48, 569-577. [CrossRef] [PubMed]

2. Chiappin, S.; Antonelli, G.; Gatti, R.; De Palo, E.F. Saliva specimen: A new laboratory tool for diagnostic and basic investigation. Clin. Chim. Acta 2007, 383, 30-40. [CrossRef] [PubMed]

3. Karnati, R.; Laurie, D.E.; Laurie, G.W. Lacritin and the tear proteome as natural replacement therapy for dry eye. Exp. Eye Res. 2013, 117, 39-52. [CrossRef] [PubMed]

4. Sitaramamma, T.; Shivaji, S.; Rao, G.N. Effect of storage on protein concentration of tear samples. Curr. Eye Res. 1998, 17, 1027-1035. [CrossRef] [PubMed]

5. Wilmarth, P.A.; Riviere, M.A.; Rustvold, D.L.; Lauten, J.D.; Madden, T.E.; David, L.L. Two-dimensional liquid chromatography study of the human whole saliva proteome. J. Proteome Res. 2004, 3, 1017-1023. [CrossRef] [PubMed]

6. Sudhof, T.C.; Rizo, J. Synaptic vesicle exocytosis. Cold Spring Harb. Perspect. Biol. 2011, 3, a005637. [CrossRef] [PubMed]

7. Sreebny, L.; Zhu, W.X. Whole saliva and the diagnosis of Sjogren's syndrome: An evaluation of patients who complain of dry mouth and dry eyes. Part 1: Screening tests. Gerodontology 1996, 13, 35-43. [CrossRef] [PubMed]

8. Jonsson, M.V.; Delaleu, N.; Brokstad, K.A.; Berggreen, E.; Skarstein, K. Impaired salivary gland function in NOD mice: Association with changes in cytokine profile but not with histopathologic changes in the salivary gland. Arthritis Rheum. 2006, 54, 2300-2305. [CrossRef] [PubMed]

9. Yamachika, C.P.; Yamachika, S.; Alford, C.E.; Cooper, C.; Pichardo, E.L.; Shah, N.; Peck, A.B.; Humphreys-Beher, M.G. Elevated levels of cysteine protease activity in saliva and salivary glands of the nonobese diabetic (NOD) mouse model for Sjogren syndrome. Proc. Natl. Acad. Sci. USA 1997, 94, 5767-5771.

10. Baldini, C.; Giusti, L.; Ciregia, F.; Da Valle, Y.; Giacomelli, C.; Donadio, E.; Sernissi, F.; Bazzichi, L.; Giannaccini, G.; Bombardieri, S.; et al. Proteomic analysis of saliva: A unique tool to distinguish primary Sjogren's syndrome from secondary Sjogren's syndrome and other sicca syndromes. Arthritis Res. Ther. 2011, 13, R194. [CrossRef] [PubMed] 
11. Piombino, P.; Genovese, A.; Esposito, S.; Moio, L.; Cutolo, P.P.; Chambery, A.; Severino, V.; Moneta, E.; Smith, D.P.; Owens, S.M.; et al. Saliva from obese individuals suppresses the release of aroma compounds from wine. PLoS ONE 2014, 9, e85611. [CrossRef] [PubMed]

12. Vors, C.; Drai, J.; Gabert, L.; Pineau, G.; Laville, M.; Vidal, H.; Guichard, E.; Michalski, M.C.; Feron, G. Salivary composition in obese vs normal-weight subjects: Towards a role in postprandial lipid metabolism? Int. J. Obes. 2015, 39, 1425-1428. [CrossRef] [PubMed]

13. Tucker, A.S. Salivary gland development. Semin. Cell Dev. Biol. 2007, 18, 237-244. [CrossRef] [PubMed]

14. Hauser, B.R.; Hoffman, M.P. Regulatory Mechanisms Driving Salivary Gland Organogenesis. Curr. Top. Dev. Biol. 2015, 115, 111-130. [PubMed]

15. Jensen, S.B.; Vissink, A. Salivary gland dysfunction and xerostomia in Sjogren's syndrome. Oral Maxillofac. Surg. Clin. N. Am. 2014, 26, 35-53. [CrossRef] [PubMed]

16. Barrera, M.J.; Bahamondes, V.; Sepulveda, D.; Quest, A.F.; Castro, I.; Cortes, J.; Aguilera, S.; Urzua, U.; Molina, C.; Perez, P.; et al. Sjogren's syndrome and the epithelial target: A comprehensive review. J. Autoimmun. 2013, 42, 7-18. [CrossRef] [PubMed]

17. Hayashi, T. Dysfunction of lacrimal and salivary glands in Sjogren's syndrome: Nonimmunologic injury in preinflammatory phase and mouse model. J. Biomed. Biotechnol. 2011, 2011, 407031. [CrossRef] [PubMed]

18. Lee, B.H.; Gauna, A.E.; Pauley, K.M.; Park, Y.J.; Cha, S. Animal models in autoimmune diseases: Lessons learned from mouse models for Sjogren's syndrome. Clin. Rev. Allergy Immunol. 2012, 42, 35-44. [CrossRef] [PubMed]

19. Park, Y.S.; Gauna, A.E.; Cha, S. Mouse Models of Primary Sjogren's Syndrome. Curr. Pharm. Des. 2015, 21, $2350-2364$. [CrossRef] [PubMed]

20. Wang, C.C.; Shi, H.; Guo, K.; Ng, C.P.; Li, J.; Gan, B.Q.; Chien Liew, H.; Leinonen, J.; Rajaniemi, H.; Zhou, Z.H.; et al. VAMP8/endobrevin as a general vesicular SNARE for regulated exocytosis of the exocrine system. Mol. Biol. Cell 2007, 18, 1056-1063. [CrossRef] [PubMed]

21. Dolai, S.; Liang, T.; Orabi, A.I.; Holmyard, D.; Xie, L.; Greitzer-Antes, D.; Kang, Y.; Xie, H.; Javed, T.A.; Lam, P.P.; et al. Pancreatitis-Induced Depletion of Syntaxin 2 Promotes Autophagy and Increases Basolateral Exocytosis. Gastroenterology 2018, 154, 1805-1821. [CrossRef] [PubMed]

22. Riedel, D.; Antonin, W.; Fernandez-Chacon, R.; Alvarez de Toledo, G.; Jo, T.; Geppert, M.; Valentijn, J.A.; Valentijn, K.; Jamieson, J.D.; Sudhof, T.C.; et al. Rab3D is not required for exocrine exocytosis but for maintenance of normally sized secretory granules. Mol. Cell. Biol. 2002, 22, 6487-6497. [CrossRef] [PubMed]

23. Meng, Z.; Edman, M.C.; Hsueh, P.Y.; Chen, C.Y.; Klinngam, W.; Tolmachova, T.; Okamoto, C.T.; Hamm-Alvarez, S.F. Imbalanced Rab3D versus Rab27 increases cathepsin S secretion from lacrimal acini in a mouse model of Sjogren's Syndrome. Am. J. Physiol. Cell Physiol. 2016, 310, C942-C954. [CrossRef] [PubMed]

24. Chiang, L.; Ngo, J.; Schechter, J.E.; Karvar, S.; Tolmachova, T.; Seabra, M.C.; Hume, A.N.; Hamm-Alvarez, S.F. Rab27b regulates exocytosis of secretory vesicles in acinar epithelial cells from the lacrimal gland. Am. J. Physiol. Cell Physiol. 2011, 301, C507-C521. [CrossRef] [PubMed]

25. Cheviet, S.; Waselle, L.; Regazzi, R. Noc-king out exocrine and endocrine secretion. Trends Cell Biol. 2004, 14, 525-528. [CrossRef] [PubMed]

26. Matsumoto, M.; Miki, T.; Shibasaki, T.; Kawaguchi, M.; Shinozaki, H.; Nio, J.; Saraya, A.; Koseki, H.; Miyazaki, M.; Iwanaga, T.; et al. Noc2 is essential in normal regulation of exocytosis in endocrine and exocrine cells. Proc. Natl. Acad. Sci. USA 2004, 101, 8313-8318. [CrossRef] [PubMed]

27. Tao, J.; Zhu, M.; Wang, H.; Afelik, S.; Vasievich, M.P.; Chen, X.W.; Zhu, G.; Jensen, J.; Ginsburg, D.; Zhang, B. SEC23B is required for the maintenance of murine professional secretory tissues. Proc. Natl. Acad. Sci USA 2012, 109, E2001-E2009. [CrossRef] [PubMed]

28. Khoriaty, R.; Everett, L.; Chase, J.; Zhu, G.; Hoenerhoff, M.; McKnight, B.; Vasievich, M.P.; Zhang, B.; Tomberg, K.; Williams, J.; et al. Pancreatic SEC23B deficiency is sufficient to explain the perinatal lethality of germline SEC23B deficiency in mice. Sci. Rep. 2016, 6, 27802. [CrossRef] [PubMed]

29. Khoriaty, R.; Vogel, N.; Hoenerhoff, M.J.; Sans, M.D.; Zhu, G.; Everett, L.; Nelson, B.; Durairaj, H.; McKnight, B.; Zhang, B.; et al. SEC23B is required for pancreatic acinar cell function in adult mice. Mol. Biol. Cell 2017, 28, 2146-2154. [CrossRef] [PubMed]

30. Gerber, S.H.; Sudhof, T.C. Molecular determinants of regulated exocytosis. Diabetes 2002, 51, S3-S11. [CrossRef] [PubMed] 
31. Mallik, R.; Gross, S.P. Molecular motors: Strategies to get along. Curr. Biol. 2004, 14, R971-R982. [CrossRef] [PubMed]

32. Ridley, A.J. Rho GTPases and actin dynamics in membrane protrusions and vesicle trafficking. Trends Cell Biol. 2006, 16, 522-529. [CrossRef] [PubMed]

33. Grosshans, B.L.; Ortiz, D.; Novick, P. Rabs and their effectors: Achieving specificity in membrane traffic. Proc. Natl. Acad. Sci. USA 2006, 103, 11821-11827. [CrossRef] [PubMed]

34. Whyte, J.R.; Munro, S. Vesicle tethering complexes in membrane traffic. J. Cell Sci. 2002, 115, $2627-2637$. [PubMed]

35. Chen, Y.A.; Scheller, R.H. SNARE-mediated membrane fusion. Nat. Rev. Mol. Cell Biol. 2001, 2, 98-106. [CrossRef] [PubMed]

36. Ngatchou, A.N.; Kisler, K.; Fang, Q.; Walter, A.M.; Zhao, Y.; Bruns, D.; Sorensen, J.B.; Lindau, M. Role of the synaptobrevin C terminus in fusion pore formation. Proc. Natl. Acad. Sci. USA 2010, 107, 18463-18468. [CrossRef] [PubMed]

37. Han, J.; Pluhackova, K.; Bockmann, R.A. The Multifaceted Role of SNARE Proteins in Membrane Fusion. Front. Physiol. 2017, 8, 5. [CrossRef] [PubMed]

38. Hong, W. SNAREs and traffic. Biochim. Biophys. Acta 2005, 1744, 493-517. [CrossRef] [PubMed]

39. Zorman, S.; Rebane, A.A.; Ma, L.; Yang, G.; Molski, M.A.; Coleman, J.; Pincet, F.; Rothman, J.E.; Zhang, Y. Common intermediates and kinetics, but different energetics, in the assembly of SNARE proteins. eLife 2014, 3, e03348. [CrossRef] [PubMed]

40. Lou, X.; Shin, Y.K. SNARE zippering. Biosci. Rep. 2016, 36, e00327. [CrossRef] [PubMed]

41. Ramakrishnan, N.A.; Drescher, M.J.; Drescher, D.G. The SNARE complex in neuronal and sensory cells. Mol. Cell. Neurosci. 2012, 50, 58-69. [CrossRef] [PubMed]

42. Gerst, J.E. SNAREs and SNARE regulators in membrane fusion and exocytosis. Cell. Mol. Life Sci. 1999, 55, 707-734. [CrossRef] [PubMed]

43. Ungermann, C.; Langosch, D. Functions of SNAREs in intracellular membrane fusion and lipid bilayer mixing. J. Cell Sci. 2005, 118, 3819-3828. [CrossRef] [PubMed]

44. Wong, S.H.; Zhang, T.; Xu, Y.; Subramaniam, V.N.; Griffiths, G.; Hong, W. Endobrevin, a novel synaptobrevin/VAMP-like protein preferentially associated with the early endosome. Mol. Biol. Cell 1998, 9, 1549-1563. [CrossRef] [PubMed]

45. Cosen-Binker, L.I.; Binker, M.G.; Wang, C.C.; Hong, W.; Gaisano, H.Y. VAMP8 is the $v$-SNARE that mediates basolateral exocytosis in a mouse model of alcoholic pancreatitis. J. Clin. Investig. 2008, 118, 2535-2551. [CrossRef] [PubMed]

46. Wang, C.C.; Ng, C.P.; Lu, L.; Atlashkin, V.; Zhang, W.; Seet, L.F.; Hong, W. A role of VAMP8/endobrevin in regulated exocytosis of pancreatic acinar cells. Dev. Cell 2004, 7, 359-371. [CrossRef] [PubMed]

47. Jones, L.C.; Moussa, L.; Fulcher, M.L.; Zhu, Y.; Hudson, E.J.; O’Neal, W.K.; Randell, S.H.; Lazarowski, E.R.; Boucher, R.C.; Kreda, S.M. VAMP8 is a vesicle SNARE that regulates mucin secretion in airway goblet cells. J. Physiol. 2012, 590, 545-562. [CrossRef] [PubMed]

48. Kamoi, M.; Ogawa, Y.; Nakamura, S.; Dogru, M.; Nagai, T.; Obata, H.; Ito, M.; Kaido, M.; Kawakita, T.; Okada, Y.; et al. Accumulation of secretory vesicles in the lacrimal gland epithelia is related to non-Sjogren's type dry eye in visual display terminal users. PLoS ONE 2012, 7, e43688. [CrossRef] [PubMed]

49. Barrera, M.J.; Sanchez, M.; Aguilera, S.; Alliende, C.; Bahamondes, V.; Molina, C.; Quest, A.F.; Urzua, U.; Castro, I.; Gonzalez, S.; et al. Aberrant localization of fusion receptors involved in regulated exocytosis in salivary glands of Sjogren's syndrome patients is linked to ectopic mucin secretion. J. Autoimmun. 2012, 39, 83-92. [CrossRef] [PubMed]

50. Jahn, R.; Sudhof, T.C. Membrane fusion and exocytosis. Annu. Rev. Biochem. 1999, 68, 863-911. [CrossRef] [PubMed]

51. Schoch, S.; Deak, F.; Konigstorfer, A.; Mozhayeva, M.; Sara, Y.; Sudhof, T.C.; Kavalali, E.T. SNARE function analyzed in synaptobrevin/VAMP knockout mice. Science 2001, 294, 1117-1122. [CrossRef] [PubMed]

52. Borisovska, M.; Zhao, Y.; Tsytsyura, Y.; Glyvuk, N.; Takamori, S.; Matti, U.; Rettig, J.; Sudhof, T.; Bruns, D. v-SNAREs control exocytosis of vesicles from priming to fusion. EMBO J. 2005, 24, 2114-2126. [CrossRef] [PubMed] 
53. Fujita-Yoshigaki, J.; Dohke, Y.; Hara-Yokoyama, M.; Furuyama, S.; Sugiya, H. Presence of a complex containing vesicle-associated membrane protein 2 in rat parotid acinar cells and its disassembly upon activation of cAMP-dependent protein kinase. J. Biol. Chem. 1999, 274, 23642-23646. [CrossRef] [PubMed]

54. Fujita-Yoshigaki, J.; Dohke, Y.; Hara-Yokoyama, M.; Kamata, Y.; Kozaki, S.; Furuyama, S.; Sugiya, H. Vesicle-associated membrane protein 2 is essential for cAMP-regulated exocytosis in rat parotid acinar cells. The inhibition of cAMP-dependent amylase release by botulinum neurotoxin B. J. Biol. Chem. 1996, 271, 13130-13134. [CrossRef] [PubMed]

55. Takuma, T.; Arakawa, T.; Tajima, Y. Interaction of SNARE proteins in rat parotid acinar cells. Arch. Oral Biol. 2000, 45, 369-375. [CrossRef]

56. Falkowski, M.A.; Thomas, D.D.; Groblewski, G.E. Complexin 2 modulates vesicle-associated membrane protein (VAMP) 2-regulated zymogen granule exocytosis in pancreatic acini. J. Biol. Chem. 2010, 285, 35558-35566. [CrossRef] [PubMed]

57. Falkowski, M.A.; Thomas, D.D.; Messenger, S.W.; Martin, T.F.; Groblewski, G.E. Expression, localization, and functional role for synaptotagmins in pancreatic acinar cells. Am. J. Physiol. Gastrointest. Liver Physiol. 2011, 301, G306-G316. [CrossRef] [PubMed]

58. Stoeckelhuber, M.; Scherer, E.Q.; Janssen, K.P.; Slotta-Huspenina, J.; Loeffelbein, D.J.; Rohleder, N.H.; Nieberler, M.; Hasler, R.; Kesting, M.R. The human submandibular gland: Immunohistochemical analysis of SNAREs and cytoskeletal proteins. J. Histochem. Cytochem. 2012, 60, 110-120. [CrossRef] [PubMed]

59. Chapman, E.R. How does synaptotagmin trigger neurotransmitter release? Annu. Rev. Biochem. 2008, 77, 615-641. [CrossRef] [PubMed]

60. Chapman, E.R. A Ca(2+) Sensor for Exocytosis. Trends Neurosci. 2018, 41, 327-330. [CrossRef] [PubMed]

61. Pang, Z.P.; Sudhof, T.C. Cell biology of $\mathrm{Ca}^{2+}$-triggered exocytosis. Curr. Opin. Cell Biol. 2010, 22, $496-505$. [CrossRef] [PubMed]

62. Wang, Z.; Liu, H.; Gu, Y.; Chapman, E.R. Reconstituted synaptotagmin I mediates vesicle docking, priming, and fusion. J. Cell Biol. 2011, 195, 1159-1170. [CrossRef] [PubMed]

63. Jo, H.; Byun, H.M.; Kim, J.H.; Kim, M.S.; Kim, S.H.; Hong, J.H.; Seo, J.T.; Lee, S.I.; Shin, D.M.; Son, H.K. Expression of $\mathrm{Ca} 2+-$ dependent synaptotagmin isoforms in mouse and rat parotid acinar cells. Yonsei Med. J. 2006, 47, 70-77. [CrossRef] [PubMed]

64. Imai, A.; Nashida, T.; Shimomura, H. mRNA expression of membrane-fusion-related proteins in rat parotid gland. Arch. Oral Biol. 2001, 46, 955-962. [CrossRef]

65. Geppert, M.; Goda, Y.; Hammer, R.E.; Li, C.; Rosahl, T.W.; Stevens, C.F.; Sudhof, T.C. Synaptotagmin I: A major $\mathrm{Ca}^{2+}$ sensor for transmitter release at a central synapse. Cell 1994, 79, 717-727. [CrossRef]

66. Reisinger, E.; Bresee, C.; Neef, J.; Nair, R.; Reuter, K.; Bulankina, A.; Nouvian, R.; Koch, M.; Buckers, J.; Kastrup, L.; et al. Probing the functional equivalence of otoferlin and synaptotagmin 1 in exocytosis. J. Neurosci. 2011, 31, 4886-4895. [CrossRef] [PubMed]

67. Pang, Z.P.; Melicoff, E.; Padgett, D.; Liu, Y.; Teich, A.F.; Dickey, B.F.; Lin, W.; Adachi, R.; Sudhof, T.C. Synaptotagmin-2 is essential for survival and contributes to $\mathrm{Ca}^{2+}$ triggering of neurotransmitter release in central and neuromuscular synapses. J. Neurosci. 2006, 26, 13493-13504. [CrossRef] [PubMed]

68. Zhao, H.; Ito, Y.; Chappel, J.; Andrews, N.W.; Teitelbaum, S.L.; Ross, F.P. Synaptotagmin VII regulates bone remodeling by modulating osteoclast and osteoblast secretion. Dev. Cell 2008, 14, 914-925. [CrossRef] [PubMed]

69. Chakrabarti, S.; Kobayashi, K.S.; Flavell, R.A.; Marks, C.B.; Miyake, K.; Liston, D.R.; Fowler, K.T.; Gorelick, F.S.; Andrews, N.W. Impaired membrane resealing and autoimmune myositis in synaptotagmin VII-deficient mice. J. Cell Biol. 2003, 162, 543-549. [CrossRef] [PubMed]

70. Sudhof, T.C.; Rothman, J.E. Membrane fusion: Grappling with SNARE and SM proteins. Science 2009, 323, 474-477. [CrossRef] [PubMed]

71. Salaun, C.; James, D.J.; Greaves, J.; Chamberlain, L.H. Plasma membrane targeting of exocytic SNARE proteins. Biochim. Biophys. Acta 2004, 1693, 81-89. [CrossRef] [PubMed]

72. Imai, A.; Nashida, T.; Shimomura, H. Intracellular localisation of SNARE proteins in rat parotid acinar cells: SNARE complexes on the apical plasma membrane. Arch. Oral Biol. 2003, 48, 597-604. [CrossRef]

73. Gaisano, H.Y.; Ghai, M.; Malkus, P.N.; Sheu, L.; Bouquillon, A.; Bennett, M.K.; Trimble, W.S. Distinct cellular locations of the syntaxin family of proteins in rat pancreatic acinar cells. Mol. Biol. Cell 1996, 7, 2019-2027. [CrossRef] [PubMed] 
74. Hansen, N.J.; Antonin, W.; Edwardson, J.M. Identification of SNAREs involved in regulated exocytosis in the pancreatic acinar cell. J. Biol. Chem. 1999, 274, 22871-22876. [CrossRef] [PubMed]

75. Pickett, J.A.; Thorn, P.; Edwardson, J.M. The plasma membrane Q-SNARE syntaxin 2 enters the zymogen granule membrane during exocytosis in the pancreatic acinar cell. J. Biol. Chem. 2005, 280, 1506-1511. [CrossRef] [PubMed]

76. Yang, C.; Coker, K.J.; Kim, J.K.; Mora, S.; Thurmond, D.C.; Davis, A.C.; Yang, B.; Williamson, R.A.; Shulman, G.I.; Pessin, J.E. Syntaxin 4 heterozygous knockout mice develop muscle insulin resistance. J. Clin. Investig. 2001, 107, 1311-1318. [CrossRef] [PubMed]

77. Spurlin, B.A.; Thurmond, D.C. Syntaxin 4 facilitates biphasic glucose-stimulated insulin secretion from pancreatic beta-cells. Mol. Endocrinol. 2006, 20, 183-193. [CrossRef] [PubMed]

78. Coursey, T.G.; Tukler Henriksson, J.; Barbosa, F.L.; de Paiva, C.S.; Pflugfelder, S.C. Interferon-gamma-Induced Unfolded Protein Response in Conjunctival Goblet Cells as a Cause of Mucin Deficiency in Sjogren Syndrome. Am. J. Pathol. 2016, 186, 1547-1558. [CrossRef] [PubMed]

79. Holt, M.; Varoqueaux, F.; Wiederhold, K.; Takamori, S.; Urlaub, H.; Fasshauer, D.; Jahn, R. Identification of SNAP-47, a novel Qbc-SNARE with ubiquitous expression. J. Biol. Chem. 2006, 281, 17076-17083. [CrossRef] [PubMed]

80. Gaisano, H.Y.; Sheu, L.; Wong, P.P.; Klip, A.; Trimble, W.S. SNAP-23 is located in the basolateral plasma membrane of rat pancreatic acinar cells. FEBS Lett. 1997, 414, 298-302. [PubMed]

81. Gaisano, H.Y.; Huang, X.; Sheu, L.; Ghai, M.; Newgard, C.B.; Trinh, K.Y.; Trimble, W.S. Snare protein expression and adenoviral transfection of amphicrine AR42J. Biochem. Biophys. Res. Commun. 1999, 260, 781-784. [CrossRef] [PubMed]

82. Suh, Y.H.; Yoshimoto-Furusawa, A.; Weih, K.A.; Tessarollo, L.; Roche, K.W.; Mackem, S.; Roche, P.A. Deletion of SNAP-23 results in pre-implantation embryonic lethality in mice. PLoS ONE 2011, 6, e18444. [CrossRef] [PubMed]

83. Suh, Y.H.; Terashima, A.; Petralia, R.S.; Wenthold, R.J.; Isaac, J.T.; Roche, K.W.; Roche, P.A. A neuronal role for SNAP-23 in postsynaptic glutamate receptor trafficking. Nat. Neurosci. 2010, 13, 338-343. [CrossRef] [PubMed]

84. Jeans, A.F.; Oliver, P.L.; Johnson, R.; Capogna, M.; Vikman, J.; Molnar, Z.; Babbs, A.; Partridge, C.J.; Salehi, A.; Bengtsson, M.; et al. A dominant mutation in Snap25 causes impaired vesicle trafficking, sensorimotor gating, and ataxia in the blind-drunk mouse. Proc. Natl. Acad. Sci. USA 2007, 104, 2431-2436. [CrossRef] [PubMed]

85. Stenmark, H.; Olkkonen, V.M. The Rab GTPase family. Genome Biol. 2001, 2, reviews3007. [CrossRef] [PubMed]

86. Barr, F.A. Review series: Rab GTPases and membrane identity: Causal or inconsequential? J. Cell Biol. 2013, 202, 191-199. [CrossRef] [PubMed]

87. Hutagalung, A.H.; Novick, P.J. Role of Rab GTPases in membrane traffic and cell physiology. Physiol. Rev. 2011, 91, 119-149. [CrossRef] [PubMed]

88. Chan, D.; Lin, J.; Raffaniello, R.D. Expression and localization of rab escort protein isoforms in parotid acinar cells from rat. J. Cell. Physiol. 2000, 185, 339-347. [CrossRef]

89. Field, R.B.; Kruse, D.H.; Redman, R.S. Immunohistochemical localization and mRNA detection of Rab3D and/or Rab3B in rat von Ebner's glands, parotid gland, pancreas, and liver. Histochem. J. 2001, 33, 71-77. [CrossRef] [PubMed]

90. Imai, A.; Yoshie, S.; Nashida, T.; Shimomura, H.; Fukuda, M. Functional involvement of Noc2, a Rab27 effector, in rat parotid acinar cells. Arch. Biochem. Biophys. 2006, 455, 127-135. [CrossRef] [PubMed]

91. Imai, A.; Fukuda, M.; Yoshie, S.; Nashida, T.; Shimomura, H. Redistribution of Rab27-specific effector Slac2-c, but not Slp4-a, after isoproterenol-stimulation in rat parotid acinar cells. Arch. Oral Biol. 2009, 54, 361-368. [CrossRef] [PubMed]

92. Imai, A.; Yoshie, S.; Ishibashi, K.; Haga-Tsujimura, M.; Nashida, T.; Shimomura, H.; Fukuda, M. EPI64 protein functions as a physiological GTPase-activating protein for Rab27 protein and regulates amylase release in rat parotid acinar cells. J. Biol. Chem. 2011, 286, 33854-33862. [CrossRef] [PubMed]

93. Imai, A.; Ishida, M.; Fukuda, M.; Nashida, T.; Shimomura, H. MADD/DENN/Rab3GEP functions as a guanine nucleotide exchange factor for Rab27 during granule exocytosis of rat parotid acinar cells. Arch. Biochem. Biophys. 2013, 536, 31-37. [CrossRef] [PubMed] 
94. Imai, A.; Tsujimura, M.; Yoshie, S.; Fukuda, M. The small GTPase Rab33A participates in regulation of amylase release from parotid acinar cells. Biochem. Biophys. Res. Commun. 2015, 461, 469-474. [CrossRef] [PubMed]

95. Nguyen, D.; Jones, A.; Ojakian, G.K.; Raffaniello, R.D. Rab3D redistribution and function in rat parotid acini. J. Cell. Physiol. 2003, 197, 400-408. [CrossRef] [PubMed]

96. Ohnishi, H.; Ernst, S.A.; Wys, N.; McNiven, M.; Williams, J.A. Rab3D localizes to zymogen granules in rat pancreatic acini and other exocrine glands. Am. J. Physiol. 1996, 271, G531-G538. [CrossRef] [PubMed]

97. Nashida, T.; Yoshie, S.; Imai, A.; Shimomura, H. Co-localization of rab4 with endocytosis-related proteins in the rat parotid glands. Arch. Histol. Cytol. 2003, 66, 45-52. [CrossRef] [PubMed]

98. Nashida, T.; Imai, A.; Shimomura, H. Relation of Rab26 to the amylase release from rat parotid acinar cells. Arch. Oral Biol. 2006, 51, 89-95. [CrossRef] [PubMed]

99. Wu, K.; Jerdeva, G.V.; da Costa, S.R.; Sou, E.; Schechter, J.E.; Hamm-Alvarez, S.F. Molecular mechanisms of lacrimal acinar secretory vesicle exocytosis. Exp. Eye Res. 2006, 83, 84-96. [CrossRef] [PubMed]

100. Xu, S.; Edman, M.; Kothawala, M.S.; Sun, G.; Chiang, L.; Mircheff, A.; Zhu, L.; Okamoto, C.; Hamm-Alvarez, S. A Rab11a-enriched subapical membrane compartment regulates a cytoskeleton-dependent transcytotic pathway in secretory epithelial cells of the lacrimal gland. J. Cell Sci. 2011, 124, 3503-3514. [CrossRef] [PubMed]

101. Raffaniello, R.D.; Lin, J.; Schwimmer, R.; Ojakian, G.K. Expression and localization of Rab3D in rat parotid gland. Biochim. Biophys. Acta 1999, 1450, 352-363. [CrossRef]

102. Ohnishi, H.; Samuelson, L.C.; Yule, D.I.; Ernst, S.A.; Williams, J.A. Overexpression of Rab3D enhances regulated amylase secretion from pancreatic acini of transgenic mice. J. Clin. Investig. 1997, 100, 3044-3052. [CrossRef] [PubMed]

103. Da Costa, S.R.; Wu, K.; Veigh, M.M.; Pidgeon, M.; Ding, C.; Schechter, J.E.; Hamm-Alvarez, S.F. Male NOD mouse external lacrimal glands exhibit profound changes in the exocytotic pathway early in postnatal development. Exp. Eye Res. 2006, 82, 33-45. [CrossRef] [PubMed]

104. Li, X.; Wu, K.; Edman, M.; Schenke-Layland, K.; MacVeigh-Aloni, M.; Janga, S.R.; Schulz, B.; Hamm-Alvarez, S.F. Increased expression of cathepsins and obesity-induced proinflammatory cytokines in lacrimal glands of male NOD mouse. Investig. Ophthalmol. Vis. Sci. 2010, 51, 5019-5029. [CrossRef] [PubMed]

105. Bahamondes, V.; Albornoz, A.; Aguilera, S.; Alliende, C.; Molina, C.; Castro, I.; Urzua, U.; Quest, A.F.; Barrera, M.J.; Gonzalez, S.; et al. Changes in Rab3D expression and distribution in the acini of Sjogren's syndrome patients are associated with loss of cell polarity and secretory dysfunction. Arthritis Rheum. 2011, 63, 3126-3135. [CrossRef] [PubMed]

106. Hamm-Alvarez, S.F.; Janga, S.R.; Edman, M.C.; Madrigal, S.; Shah, M.; Frousiakis, S.E.; Renduchintala, K.; Zhu, J.; Bricel, S.; Silka, K.; et al. Tear cathepsin S as a candidate biomarker for Sjogren's syndrome. Arthritis Rheum. 2014, 66, 1872-1881. [CrossRef] [PubMed]

107. Edman, M.C.; Janga, S.R.; Meng, Z.; Bechtold, M.; Chen, A.F.; Kim, C.; Naman, L.; Sarma, A.; Teekappanavar, N.; Kim, A.Y.; et al. Increased Cathepsin $S$ activity associated with decreased protease inhibitory capacity contributes to altered tear proteins in Sjogren's Syndrome patients. Sci. Rep. 2018, 8, 11044. [CrossRef] [PubMed]

108. Verhage, M.; Maia, A.S.; Plomp, J.J.; Brussaard, A.B.; Heeroma, J.H.; Vermeer, H.; Toonen, R.F.; Hammer, R.E.; van den Berg, T.K.; Missler, M.; et al. Synaptic assembly of the brain in the absence of neurotransmitter secretion. Science 2000, 287, 864-869. [CrossRef] [PubMed]

109. Heeroma, J.H.; Roelandse, M.; Wierda, K.; van Aerde, K.I.; Toonen, R.F.; Hensbroek, R.A.; Brussaard, A.; Matus, A.; Verhage, M. Trophic support delays but does not prevent cell-intrinsic degeneration of neurons deficient for munc18-1. Eur. J. Neurosci. 2004, 20, 623-634. [CrossRef] [PubMed]

110. Fukuda, M.; Imai, A.; Nashida, T.; Shimomura, H. Slp4-a/granuphilin-a interacts with syntaxin-2/3 in a Munc18-2-dependent manner. J. Biol. Chem. 2005, 280, 39175-39184. [CrossRef] [PubMed]

111. Dolai, S.; Liang, T.; Lam, P.P.L.; Fernandez, N.A.; Chidambaram, S.; Gaisano, H.Y. Effects of ethanol metabolites on exocytosis of pancreatic acinar cells in rats. Gastroenterology 2012, 143, 832-843. [CrossRef] [PubMed]

112. Gutierrez, B.A.; Chavez, M.A.; Rodarte, A.I.; Ramos, M.A.; Dominguez, A.; Petrova, Y.; Davalos, A.J.; Costa, R.M.; Elizondo, R.; Tuvim, M.J.; et al. Munc18-2, but not Munc18-1 or Munc18-3, controls compound and single-vesicle-regulated exocytosis in mast cells. J. Biol. Chem. 2018, 293, 7148-7159. [CrossRef] [PubMed]

113. Kim, K.; Petrova, Y.M.; Scott, B.L.; Nigam, R.; Agrawal, A.; Evans, C.M.; Azzegagh, Z.; Gomez, A.; Rodarte, E.M.; Olkkonen, V.M.; et al. Munc18b is an essential gene in mice whose expression is limiting for secretion by airway epithelial and mast cells. Biochem. J. 2012, 446, 383-394. [CrossRef] [PubMed] 
114. Imai, A.; Nashida, T.; Shimomura, H. Roles of Munc18-3 in amylase release from rat parotid acinar cells. Arch. Biochem. Biophys. 2004, 422, 175-182. [CrossRef] [PubMed]

115. Gaisano, H.Y.; Lutz, M.P.; Leser, J.; Sheu, L.; Lynch, G.; Tang, L.; Tamori, Y.; Trimble, W.S.; Salapatek, A.M. Supramaximal cholecystokinin displaces Munc18c from the pancreatic acinar basal surface, redirecting apical exocytosis to the basal membrane. J. Clin. Investig. 2001, 108, 1597-1611. [CrossRef] [PubMed]

116. Oh, E.; Thurmond, D.C. Munc18c depletion selectively impairs the sustained phase of insulin release. Diabetes 2009, 58, 1165-1174. [CrossRef] [PubMed]

117. Fukuda, M. Distinct Rab binding specificity of Rim1, Rim2, rabphilin, and Noc2. Identification of a critical determinant of Rab3A/Rab27A recognition by Rim2. J. Biol. Chem. 2003, 278, 15373-15380. [CrossRef] [PubMed]

118. Teramae, H.; Fujimoto, W.; Seino, S.; Iwanaga, T. Cellular expression of Noc2, a Rab effector protein, in endocrine and exocrine tissues in the mouse. Histochem. Cell Biol. 2007, 127, 1-11. [CrossRef] [PubMed]

119. Lord, C.; Ferro-Novick, S.; Miller, E.A. The highly conserved COPII coat complex sorts cargo from the endoplasmic reticulum and targets it to the golgi. Cold Spring Harb. Perspect. Biol. 2013, 5, a013367. [CrossRef] [PubMed]

120. Lord, C.; Bhandari, D.; Menon, S.; Ghassemian, M.; Nycz, D.; Hay, J.; Ghosh, P.; Ferro-Novick, S. Sequential interactions with Sec23 control the direction of vesicle traffic. Nature 2011, 473, 181-186. [CrossRef] [PubMed]

121. Townley, A.K.; Feng, Y.; Schmidt, K.; Carter, D.A.; Porter, R.; Verkade, P.; Stephens, D.J. Efficient coupling of Sec23-Sec24 to Sec13-Sec31 drives COPII-dependent collagen secretion and is essential for normal craniofacial development. J. Cell Sci. 2008, 121, 3025-3034. [CrossRef] [PubMed]

122. Boyadjiev, S.A.; Fromme, J.C.; Ben, J.; Chong, S.S.; Nauta, C.; Hur, D.J.; Zhang, G.; Hamamoto, S.; Schekman, R.; Ravazzola, M.; et al. Cranio-lenticulo-sutural dysplasia is caused by a SEC23A mutation leading to abnormal endoplasmic-reticulum-to-Golgi trafficking. Nat. Genet. 2006, 38, 1192-1197. [CrossRef] [PubMed]

123. Fromme, J.C.; Ravazzola, M.; Hamamoto, S.; Al-Balwi, M.; Eyaid, W.; Boyadjiev, S.A.; Cosson, P.; Schekman, R.; Orci, L. The genetic basis of a craniofacial disease provides insight into COPII coat assembly. Dev. Cell 2007, 13, 623-634. [CrossRef] [PubMed]

124. Khoriaty, R.; Hesketh, G.G.; Bernard, A.; Weyand, A.C.; Mellacheruvu, D.; Zhu, G.; Hoenerhoff, M.J.; McGee, B.; Everett, L.; Adams, E.J.; et al. Ginsburg, Functions of the COPII gene paralogs SEC23A and SEC23B are interchangeable in vivo. Proc. Natl. Acad. Sci. USA 2018, 115, E7748-E7757. [CrossRef] [PubMed]

125. Lang, M.R.; Lapierre, L.A.; Frotscher, M.; Goldenring, J.R.; Knapik, E.W. Secretory COPII coat component Sec23a is essential for craniofacial chondrocyte maturation. Nat. Genet. 2006, 38, 1198-1203. [CrossRef] [PubMed]

126. Russo, R.; Esposito, M.R.; Iolascon, A. Inherited hematological disorders due to defects in coat protein (COP)II complex. Am. J. Hematol. 2013, 88, 135-140. [CrossRef] [PubMed]

127. Charcosset, M.; Sassolas, A.; Peretti, N.; Roy, C.C.; Deslandres, C.; Sinnett, D.; Levy, E.; Lachaux, A. Anderson or chylomicron retention disease: Molecular impact of five mutations in the SAR1B gene on the structure and the functionality of Sar1b protein. Mol. Genet. Metab. 2008, 93, 74-84. [CrossRef] [PubMed]

128. Jones, B.; Jones, E.L.; Bonney, S.A.; Patel, H.N.; Mensenkamp, A.R.; Eichenbaum-Voline, S.; Rudling, M.; Myrdal, U.; Annesi, G.; Naik, S.; et al. Mutations in a Sar1 GTPase of COPII vesicles are associated with lipid absorption disorders. Nat Genet. 2003, 34, 29-31. [CrossRef] [PubMed]

129. Bianchi, P.; Fermo, E.; Vercellati, C.; Boschetti, C.; Barcellini, W.; Iurlo, A.; Marcello, A.P.; Righetti, P.G.; Zanella, A. Congenital dyserythropoietic anemia type II (CDAII) is caused by mutations in the SEC23B gene. Hum. Mutat. 2009, 30, 1292-1298. [CrossRef] [PubMed]

130. Schwarz, K.; Iolascon, A.; Verissimo, F.; Trede, N.S.; Horsley, W.; Chen, W.; Paw, B.H.; Hopfner, K.P.; Holzmann, K.; Russo, R.; et al. Mutations affecting the secretory COPII coat component SEC23B cause congenital dyserythropoietic anemia type II. Nat. Genet. 2009, 41, 936-940. [CrossRef] [PubMed]

131. Lukach, L.; Maly, A.; Zini, A.; Aframian, D.J. Morphometrical study of minor salivary gland in xerostomic patients with altered lipid metabolis. Oral Dis. 2014, 20, 714-719. [CrossRef] [PubMed]

132. Saito, T.; Shimazaki, Y. Metabolic disorders related to obesity and periodontal disease. Periodontol 2000, 43, 254-266. [CrossRef] [PubMed]

133. Dodds, M.W.; Yeh, C.K.; Johnson, D.A. Salivary alterations in type 2 (non-insulin-dependent) diabetes mellitus and hypertension. Commun. Dent. Oral Epidemiol. 2000, 28, 373-381. [CrossRef] 
134. Border, M.B.; Schwartz, S.; Carlson, J.; Dibble, C.F.; Kohltfarber, H.; Offenbacher, S.; Buse, J.B.; Bencharit, S. Exploring salivary proteomes in edentulous patients with type 2 diabetes. Mol. Biosyst. 2012, 8, 1304-1310. [CrossRef] [PubMed]

135. Izumi, M.; Zhang, B.X.; Dean, D.D.; Lin, A.L.; Saunders, M.J.; Hazuda, H.P.; Yeh, C.K. Secretion of salivary statherin is compromised in uncontrolled diabetic patients. BBA Clin. 2015, 3, 135-140. [CrossRef] [PubMed]

136. Bencharit, S.; Baxter, S.S.; Carlson, J.; Byrd, W.C.; Mayo, M.V.; Border, M.B.; Kohltfarber, H.; Urrutia, E.; Howard-Williams, E.L.; Offenbacher, S.; et al. Salivary proteins associated with hyperglycemia in diabetes: A proteomic analysis. Mol. Biosyst. 2013, 9, 2785-2797. [CrossRef] [PubMed]

137. Kalburgi, V.; Leburu, S.; Warad, S. Saliva as a surrogate to explore the association between lipid profiles and chronic periodontitis: A case-control study. Dent. Res. J. 2014, 11, 619-623.

138. Rao, P.V.; Reddy, A.P.; Lu, X.; Dasari, S.; Krishnaprasad, A.; Biggs, E.; Roberts, C.T.; Nagalla, S.R. Proteomic identification of salivary biomarkers of type-2 diabetes. J. Proteome Res. 2009, 8, 239-245. [CrossRef] [PubMed]

139. Lehmann-Kalata, A.; Miechowicz, I.; Korybalska, K.; Swora-Cwynar, E.; Czepulis, N.; Luczak, J.; Orzechowska, Z.; Grzymislawski, M.; Surdacka, A.; Witowski, J. Salivary fingerprint of simple obesity. Cytokine 2018, 110, 174-180. [CrossRef] [PubMed]

140. Ueda, H.; Yagi, T.; Amitani, H.; Asakawa, A.; Ikeda, S.; Miyawaki, S.; Inui, A. The roles of salivary secretion, brain-gut peptides, and oral hygiene in obesity. Obes. Res. Clin. Pract. 2013, 7, e321-e329. [CrossRef] [PubMed]

141. Lasisi, T.J.; Shittu, S.T.; Alada, A.R. Re-establishing normal diet following high fat-diet-induced obesity reverses the altered salivary composition in Wistar rats. J. Basic Clin. Physiol. Pharmacol. 2018. [CrossRef] [PubMed]

142. Fujita, Y.; Maki, K. High-fat diet-induced obesity triggers alveolar bone loss and spontaneous periodontal disease in growing mice. BMC Obes. 2015, 3, 1. [CrossRef] [PubMed]

143. Macri, E.; Lifshitz, F.; Ramos, C.; Orzuza, R.; Costa, O.; Zago, V.; Boyer, P.; Friedman, S. Atherogenic cholesterol-rich diet and periodontal disease. Arch. Oral Biol. 2014, 59, 679-686. [CrossRef] [PubMed]

144. Muluke, M.; Gold, T.; Kiefhaber, K.; Al-Sahli, A.; Celenti, R.; Jiang, H.; Cremers, S.; Van Dyke, T.; Schulze-Spate, U. Diet-Induced Obesity and Its Differential Impact on Periodontal Bone Loss. J. Dent. Res. 2016, 95, 223-229. [CrossRef] [PubMed]

145. Kondo, K.; Ishikado, A.; Morino, K.; Nishio, Y.; Ugi, S.; Kajiwara, S.; Kurihara, M.; Iwakawa, H.; Nakao, K.; Uesaki, S.; et al. A high-fiber, low-fat diet improves periodontal disease markers in high-risk subjects: A pilot study. Nutr. Res. 2014, 34, 491-498. [CrossRef] [PubMed]

146. Edwards, A.V.; Titchen, D.A. The effect of parasympathetic postganglionic denervation on parotid salivary protein secretion in anaesthetized sheep. Auton. Neurosci. 2002, 100, 50-57. [CrossRef]

147. Kang, J.H.; Kim, B.K.; Park, B.I.; Kim, H.J.; Ko, H.M.; Yang, S.Y.; Kim, M.S.; Jung, J.Y.; Kim, W.J.; Oh, W.M.; et al. Parasympathectomy induces morphological changes and alters gene-expression profiles in the rat submandibular gland. Arch. Oral Biol. 2010, 55, 7-14. [CrossRef] [PubMed]

148. Matsuo, R.; Garrett, J.R.; Proctor, G.B.; Carpenter, G.H. Reflex secretion of proteins into submandibular saliva in conscious rats, before and after preganglionic sympathectomy. J. Physiol. 2000, 527, 175-184. [CrossRef] [PubMed]

149. Raz, E.; Saba, L.; Hagiwara, M.; Hygino de Cruz, L.C., Jr.; Som, P.M.; Fatterpekar, G.M. Parotid gland atrophy in patients with chronic trigeminal nerve denervation. AJNR Am. J. Neuroradiol. 2013, 34, 860-863. [CrossRef] [PubMed]

150. Zhang, S.E.; Su, Y.X.; Zheng, G.S.; Liang, Y.J.; Liao, G.Q. Reinnervated nerves contribute to the secretion function and regeneration of denervated submandibular glands in rabbits. Eur. J. Oral Sci. 2014, 122, 372-381. [CrossRef] [PubMed]

(C) 2018 by the authors. Licensee MDPI, Basel, Switzerland. This article is an open access article distributed under the terms and conditions of the Creative Commons Attribution (CC BY) license (http:/ / creativecommons.org/licenses/by/4.0/). 